\title{
Strategies of Successful English Language Learners among Private School Students
}

\author{
Stella Ang, Mohamed Amin Embi, Melor Md. Yunus \\ Universiti Kebangsaan Malaysia, Malaysia \\ E-mail: stellaang2@gmail.com,embi.mohamedamin@gmail.com,melor@ukm.edu.my
}

\begin{abstract}
This study is designed to identify the area of language learning strategies that were employed by ten successful English Language Learners of Form Five from a private secondary school in Kuching, Sarawak. The strategies used by these learners help promote and boost the use of strategies among poor language learners. Using a purposive sampling procedure, a group comprising of ten successful language learners of a private school in Kuching, Sarawak participated in the study. The findings indicated that successful language learners are high frequency users of language learning strategies. The findings revealed that metacognitive strategies are among the highest frequently used strategies, followed correspondingly by social, cognitive, compensation, affective and memory strategies found as the least used strategies among successful language learners. Interestingly, the study acknowledged that successful language learners employed more indirect strategies paralleled to direct strategies. The findings have significant implications for research on language learning strategies concerning successful language learners and teacher planning to cater the needs of diverse learners in English Language and improve the field of language teaching.
\end{abstract}

Key Words: language learning strategies, successful language learners, english as a second language

\begin{abstract}
Abstrak: Penelitian ini dirancang untuk mengidentifikasi area strategi pembelajaran bahasa yang digunakan oleh sepuluh pebelajar Bahasa Inggris yang berhasil di lima sekolah menengah swasta di Kuching, Sarawak. Strategi yang digunakan oleh pebelajar ini membantu untuk mempromosikan dan meningkatkan penggunaan strategi di antara pebelajar dengan Bahasa yang dianggap kurang. Dengan menggunakan prosedur purposive sampling, sekelompok yang terdiri dari sepuluh pebelajar bahasa yang berhasil belajar di sebuah sekolah swasta di Kuching, Sarawak berpartisipasi dalam penelitian ini. Temuan penelitian ini menunjukkan bahwa pebelajar bahasa yang berhasil adalah pebelajar yang menggunakan strategi pembelajaran bahasa frekuensi tinggi. Temuan tersebut mengungkapkan bahwa strategi metakognitif adalah strategi yang paling sering digunakan, diikuti oleh strategi sosial, kognitif, kompensasi, afektif dan memori yang ditemukan sebagai strategi yang paling sedikit digunakan di antara pelajar bahasa yang berhasil. Menariknya, penelitian ini mengakui bahwa pebelajar bahasa yang sukses menggunakan lebih banyak strategi tidak langsung yang sejalan dengan strategi langsung. Temuan ini memiliki implikasi yang signifikan terhadap penelitian tentang strategi pembelajaran bahasa mengenai pebelajar bahasa yang berhasil dan perencanaan guru untuk memenuhi kebutuhan pebelajar yang beragam dalam Bahasa Inggris dan memperbaiki bidang pengajaran bahasa.
\end{abstract}

Kata kunci: strategi belajar bahasa, pebelajar bahasa yang sukses, bahasa inggris sebagai bahasa kedua

Learners learn in a variety of ways and strategies. It is inevitable that learners should be given proper strategy instruction and training in order to create awareness of the existence of their own strategies and train learners in their practice. Based on a review of literature by Cohen \& Griffiths (2015), learners consciously take charge of their own learning through an organized manner, reflecting the target language and practice the language effectively for knowledge retention and application of the knowledge learnt. Learners also internalized language learning and by dealing with problem solving techniques, learners utilize more strategies which involve in the complex process of learning. Two studies portray similar view in which Razak, Ismail, 
Aziz, \& Babikkoi, (2012) and Yunus, Sulaiman, \& Embi (2013) postulated that learning performance could be enhanced by integrating deliberate behaviour and opinions when language learning occurs. Since learners no longer becomes passive receptacles for knowledge, learners who utilize thinking skills are more accountable of their own learning and exchanging ideas for the development of language. It is against this backdrop that this study was conducted with the aims to discover strategy use among second language learners in Tunku Putra School to explore further at the appropriate strategy commonly put into practice by successful learners.

In the review of the research literature, Rubin (1975), Stern (1975) Naiman, et al. (1978) and Oxford (2003) discovered that second language learners typically employed higher frequency of strategies as compared to foreign language learners. In the Malaysian classroom setting, successful language learners often take an active role in discussion and demonstrate good understanding of the target language through the use of suitable learning strategies. This is certainly applicable to the 21 st century learners as in the Malaysian blueprint highlights the need to create self-directed and autonomus learners. In fact, most of the research pertaining to LLS focuses on good language learners (e.g. Naiman et, al, 1975, Mohamed Amin Embi, 1996; 2000) factors influencing choice of LLS (Oxford \& Nyikos,1989; Khamkhien, 2010; Genc and Aydin, 2011; El-Omari, 2016), relationship among LLS (Griffiths \& Inceçay; 2016; Varasteh, Ghanizadeh \& Akbari, 2016) variables of individual differences and learning outcomes (Schmidt, 2012; Riding and Rayner, 2015; Entwistle and Ramsden, 2015). Besides, Bidabadi and Yamat (2011), Razak et. al (2012), Ghafournia (2014) and Yunus, Sulaiman and Embi (2013) revealed on a significant relationship between the application of strategy and the language proficiency among ESL. One of the areas of research in Language Learning Strategies is on the Successful Language Learner. Although much research has been said about Successful Language Learner (e.g. Naimen et.al, 1975, Amin, 1996; 2000) not much is known about Successful Language Learner in the private secondary school contexts. The purpose of this study is designed to identify language learning strategies employed by successful language learners in a private secondary school in Kuching which is Tunku Putra School.

\section{Definitions of Language Learning Strategies}

According to Wenden and Rubin (1987) learning strategies can be defined as a flexible approach use of operations, steps, plans, routines for the learner to assist with the obtaining, storing, retrieving, and using of information. Correspondingly, Chamot, \& Kupper (1989) and O' Malley \& Chamot (1990) also acknowledge that language learning strategies are specific thoughts and action to maximize learning process, comprehension, storing and remembering new input and skills. Despite copious definition of learning strategies gathered by scholars, there is a fair degree of consensus between scholars in terms of goal orientation and action basis in language learning strategies. According to Chuin and Kaur (2015), the deployment of language learning strategies could facilitate language performance due to the fact that learners are engaged in an active process of learning whereby the use of mental processing involved with the aims of achieving specific goals, learning strategies or techniques. This is in accordance to Oxford (1990) who proposed that language learning strategies are certain actions carried out by learners which help learners to make learning easier, exciting, more autonomous, more successful and more adaptable to current learning situations.

\section{Characteristics of Successful Language Learners}

Rubin (1975), Stern (1975) and Naiman, et. al. (1978), Chen \& Xiao (2016) and Rao (2016) suggested that a greater awareness of strategy use among students exert higher influence on learners' language proficiency. Rubin and Thompson (1994) as well as Mohammed Amin (2000), have characterized some wide language strategies used by the successful language learners. In the various language skill, learners adopt a particular strategy to facilitate their language learning. With reference to Dörnyei, \& Ryan (2015) who asserted that second language learners attainment relies on the students' own active and creative participation in the strategies or tech-niques used during the learning process. In this context, Chan (2016) has identified that learning outside the classroom promotes better learning performance as well as opportunity to be engaged in a fruitful academic. Mohamed Amin Embi et al. (2001) and Javid, C. et. al (2013) also advocated that successful learners demonstrate better application 
of language learning strategies as compared to the less proficient learners and that the partctipants with high English language proficiency adopt language learning strategies more frequently. This evidence is supported by Samah et. al (2016) who claim that the outstanding learners possess their own methods in language learning and build their own situations in acquiring concepts. Consequently, learning strategies for second language learners assist to develop learner autonomy, which requires the learner to take conscious control of his or her own learning processes (Bree, 2014).

\section{METHOD}

This study was designed to investigate the language learning strategies used by upper secondary students, ESL (English as a second language) learners studying in Tunku Putra School through a set of questionnaire.

In this study, purposive sampling method is used wherein ten students were selected to be the respondents. In the same way as non-probability sampling technique, this method was chosen to make certain the sample possessed the same characteristic which was good language learners. The participants of this study were ten Form Five students of Tunku Putra School, which were two males and eight females. The researcher used purposive sampling method in order to select the ten representatives of the population. This sampling method is used as a process of selecting a sample that is believed to be the representative of a given population.

The purpose of this study was to investigate learners use of learning strategies for the solutions of the language learners of the Tunku Putra School. In the current study, the researcher applied a quantitative method by using a questionnaire to collect data and interpreting the findings in terms of their learning strategies. The details of the participants, questionnaire, data collection and data analysis are described as follows.

The data collection instrument used in this study was based on Oxford's taxonomy. Oxford's Strategy Inventory for Language Learning (SILL) Version 7.0 was used in order to obtain information pertaining to the topic. Oxford's (1990) Strategy Inventory for Language Learning or SILL Version 7.0 is a 50 items survey which is reliable and is applicable to the English as a second language (ESL) and English as Foreign Language (EFL) learners with diverse cultural back- ground. For example, the Arabic, Chinese, Hispanic, and Japanese students used Oxford's taxonomy for the purpose of such study. (Huang, 2015; Razak et.al, 2012; Barrios, 2015; and Kobayashi, R., 2016). Furthermore, the reliability and validity of the questionnaire have been broadly tested and verified (Oxford, 1992) which explains the appropriateness of this questionnaire for the current study. Additionally, the SILL questionnaire developed by Oxford (1990) was adopted in the study because it is one of the most widely accepted assessment tool for language learning startegies around the world and it has been translated into at least 17 languages (Oxford, 1999). The inventory consists of fifty items on which they marked their responses on a Likert scale of five points, ranging from 1 for "Never or almost never true of me" to 5 for "Always or almost always true of me." The respondents completed the questionnaire during the stipulated time given for 25 minutes under the supervision of the researcher.

A questionnaire was used to investigate and gather information about the successful language learners strategies use. The questionnaire consists two sections. Section one was designed to obtain demographic information about the samples regarding age and gender. The second section consisted of a set of questions related to language learning strategies. In this construct, fifty items were used to investigate the participants' frequency of utilization of various language learning strategies. Here, a fifty items with a five-point Likert scale of 'Strongly Disagree', 'Disagree', 'Neutral' 'Agree' and 'Strongly agree'. The respondents were required to indicate their level of needs to indicate their language skills improvement. The questionnaire used in this study was adapted based on Oxford's SILL (1990) which was divided into six parts based on Oxford's (1990) classification of language learning strategies.

Data collected from the questionnaires were analyzed using descriptive statistic using frequency counts. Descriptive statistics using frequency counts were conducted for all the items in the questionnaire to explore successful language learners strategies use in order to improve the English skills of Tunku Putra school students respectively. All the questionnaire items were designed on the basis of five point Likert Scale of the agreement.

A total mean score was employed in order to determine the frequency of language learning strategies used. The rating of frequency employed from the SILL was separated into three major categories of use. To 
determine the frequency of language learning strategies used, an interpretation mean score was employed. Students' responses were categorized into three categories, which were high, moderate and low frequency use of language strategy. Reporting frequency of use in learning strategies, strategy inventory for language learning (SILL) developed by (Oxford, 1990) provides the basic framework to understand the mean score on the students' SILL and the level of need, which

Table 1. The Interpretation Data of Frequency Use Learning Strategies

\begin{tabular}{ll}
\hline High strategy use & $\mathbf{3 . 5}$ to $\mathbf{5 . 0}$ \\
\hline Medium strategy use & 2.5 to 3.4 \\
\hline Low strategy use & 1.0 to 2.4 \\
\hline
\end{tabular}

has a scale range of $1-5$. Mean of 1.0 to 2.4 was considered as low strategy use, 2.5 to 3.4 were characterized into medium strategy use and mean of 3.5 to 5.0 was considered as high strategy use (Table 1).

The researchers administered the questionnaires in July for the actual study. A total of these ten form five students responded to the questionnaires. The questionnaires were given to the respondents during their class hours and a half hour is given to complete the questionnaire. The return rates were $100 \%$ and all the completed questionnaires were used for data entry.

\section{RESULTS}

\section{Overall Strategy Use}

Based on Table 2, the mean of the overall strategy use was 3.712. The result shows that successful language learners deployed high strategy use. Besides, the students were also found to possess high level in the frequency use for three categories namely metacognitive, social and cognitive with the mean score between 4.036 and 4.466. Conversely, it was also acknowledged that there were three categories namely

Table 2. Mean Scores and Frequency of Language Learning Strategies Usage

\begin{tabular}{lccc}
\hline \multicolumn{1}{c}{ Strategy } & Mean & Frequency & Rank \\
\hline Metacognitive & 4.466 & High & 1 \\
Social & 4.217 & High & 2 \\
Cognitive & 4.036 & High & 3 \\
Compensation & 3.450 & High & 4 \\
Affective & 3.233 & Medium & 5 \\
Memory & 2.867 & Medium & 6 \\
\hline Total & 3.712 & & \\
\hline
\end{tabular}

compensation, affective and memory which were regarded as medium frequency of use. The range is between 2.867 and 3.450. The most frequently used language learning strategies was metacognitive strategies with the mean of 4.466 , while memory strategies recorded to be the lowest mean scores that is 2.867 .

\section{Learners' Strategy Use}

To highlight the learners' strategy use, descriptive statistics of frequency and percentages were utilized. As aforementioned, the instrument to assess the learners' strategy use is the English as a second language Strategy Use Survey developed based on Cohen, Oxford and Chi (2005).

\section{Individual Strategy Use}

The total means and the description of frequency use of each item were presented according to their categories. Generally, the statistics indicated that a total of 35 out of 50 strategies recorded to be in the high level of use category (Mean=3.50 to 5.00) the 11 remaining items were recorded to be medium frequency of use (Mean=2.50 to 3.40) and 4 items left were recorded as low frequency use (Mean $=1.20$ to 2.40).

\section{Memory}

The mean score indicated that three items were at high scale of frequency with mean scores ranging from 3.60 to 4.00 for the strategies used (Table 3). The item which showed the highest mean score was "I remember new English words or phrases by remembering their location on the page, on the board, or on a street sign". Since the medium of instruction and daily conversation in the school is English, engaging in the language used is important among the students. The disparity lies in the item that portrays the lowest mean score which was on "I use flashcards to remember new English words". According to Saeed Mojarradi (2014) in his article entitled "The effects of using flashcards on ESL students' ability to learn vocabulary", he discovered the use of flashcards came on ESL students' ability to learn vocabulary. Additionally, a study carried out by Baleghizadeh and Ashoori (2011) also stated that there was no significant impact in the use of flashcards towards increase performance of learning strategy. The finding of the study implied flashcards were not favoured as a learning strategy, there- 
Table 3. Mean Scores and Percentage of Memory Strategy

\begin{tabular}{|c|c|c|c|c|c|c|c|}
\hline Statement & 1 & 2 & 3 & 4 & 5 & Mean & $\begin{array}{l}\text { Frequency } \\
\text { Level }\end{array}$ \\
\hline $\begin{array}{l}\text { I remember new English words or phrases } \\
\text { by remembering their location on the page, } \\
\text { on the board, or on a street sign. }\end{array}$ & $\begin{array}{c}1 \\
(10 \%)\end{array}$ & $\begin{array}{c}2 \\
(20 \%)\end{array}$ & $\begin{array}{c}3 \\
(30 \%)\end{array}$ & $\begin{array}{c}4 \\
(40 \%)\end{array}$ & $\begin{array}{c}2 \\
(20 \%)\end{array}$ & 4.0 & High \\
\hline $\begin{array}{l}\text { I use flashcards to remember new English } \\
\text { words. }\end{array}$ & $\begin{array}{c}8 \\
(80 \%)\end{array}$ & $\begin{array}{c}2 \\
(20 \%)\end{array}$ & - & - & - & 1.2 & Low \\
\hline
\end{tabular}

Table 4. Mean Scores and Percentage of Cognitive Strategy

\begin{tabular}{|c|c|c|c|c|c|c|c|}
\hline Statement & 1 & 2 & 3 & 4 & 5 & Mean & $\begin{array}{c}\text { Frequency } \\
\text { Level }\end{array}$ \\
\hline $\begin{array}{l}\text { I start conversations in } \\
\text { English. }\end{array}$ & - & - & - & $\begin{array}{c}2 \\
(20 \%)\end{array}$ & $\begin{array}{c}8 \\
(80 \%)\end{array}$ & 4.8 & High \\
\hline $\begin{array}{l}\text { I try to find patterns in } \\
\text { English. }\end{array}$ & - & $\begin{array}{c}2 \\
(20 \%)\end{array}$ & $\begin{array}{c}3 \\
(30 \%)\end{array}$ & $\begin{array}{c}4 \\
(40 \%)\end{array}$ & $\begin{array}{c}1 \\
(10 \%)\end{array}$ & 3.4 & Medium \\
\hline
\end{tabular}

Table 5. Mean Scores and Percentage of Compensation Strategy

\begin{tabular}{|c|c|c|c|c|c|c|c|}
\hline Statement & 1 & 2 & 3 & 4 & 5 & Mean & $\begin{array}{l}\text { Frequency } \\
\text { Level }\end{array}$ \\
\hline $\begin{array}{l}\text { If I cannot think of an English word, I use } \\
\text { a word or phrase that means the same } \\
\text { thing. }\end{array}$ & - & - & $\begin{array}{c}1 \\
(10 \%)\end{array}$ & $\begin{array}{c}6 \\
(60 \%)\end{array}$ & $\begin{array}{c}3 \\
(30 \%)\end{array}$ & 4.2 & High \\
\hline $\begin{array}{l}\text { I make up new words if I don't know the } \\
\text { right ones in English }\end{array}$ & $\begin{array}{c}2 \\
(20 \%)\end{array}$ & $\begin{array}{c}3 \\
(30 \%)\end{array}$ & $\begin{array}{c}3 \\
(30 \%)\end{array}$ & $\begin{array}{c}2 \\
(20 \%)\end{array}$ & - & 2.5 & Medium \\
\hline
\end{tabular}

fore supported the aforementioned literature reviews. Although flashcards might lead language learners to a higher level of vocabulary enchancment as postulated by Komachali and Khodareza (2012), it continued to be in the field of research and have shown evidence in a number of comprehensive study.

\section{Cognitive}

The mean score designated that 14 items showed a high scale of frequency with mean scores ranging from 3.60 to 4.80 for cognitive strategies (Table 4). The item which indicated the highest mean score was "I start conversations in English". The item that has the lowest mean score was "I try to find patterns in English". Many researchers explored the importance of starting conversation in English as it promotes the practical use of language and authentic surroundings in which the language is used orally (Goldenberg, 2013).The researcher also found that starting conversation in English can engage students with the discussion and enhance their language learning as well as capture the learner's attention and in turn positively increase the learner's motivation to learn English (Karas, 2016). The above findings were consistent and significantly relevant to the results of this study as majority of the ten respondents reflected their opinions as 'strongly agreed' that they prefer starting conversations in English.

\section{Compensation}

The mean scores specified that three items are at high scale of frequency with mean scores ranging from 3.80 to 4.20 for compensatory strategies (Table 5). The highest mean score was "If I cannot think of an English word, I use a word or phrase that means the same thing". Oxford (1900) claimed that compensation strategies can be beneficial to overcome knowledge limitations in all four skills. The results suggested that majority of the respondents utilized compensation learning strategy to tackle gaps they encountered concerning their knowledge on the target language with nine altogether interpreted their opinions as 'agreed' and 'strongly agreed'. On the opposite, the lowest mean score was "I make up new words if I do not know the right ones in English". Five respondents were positive towards this strategy while another five respondents were negative. This was probability due to unfamiliarity to the technique which therefore led to minimum exploration. 
Table 6. Mean Scores and Percentage of Metacognitive Strategy

\begin{tabular}{|c|c|c|c|c|c|c|c|}
\hline Statement & 1 & 2 & 3 & 4 & 5 & Mean & Frequency Level \\
\hline $\begin{array}{l}\text { I notice my English mistakes and use } \\
\text { that information to help me do better. }\end{array}$ & - & - & $\begin{array}{c}1 \\
(10 \%)\end{array}$ & $\begin{array}{c}2 \\
(20 \%)\end{array}$ & $\begin{array}{c}7 \\
(70 \%)\end{array}$ & 4.6 & High \\
\hline $\begin{array}{l}\text { I try to find out how to be a better } \\
\text { learner of English. }\end{array}$ & - & - & $\begin{array}{c}1 \\
(10 \%)\end{array}$ & $\begin{array}{c}1 \\
(10 \%)\end{array}$ & $\begin{array}{c}8 \\
(80 \%)\end{array}$ & 4.7 & High \\
\hline $\begin{array}{l}\text { I have clear goals for improving my } \\
\text { English skills. }\end{array}$ & - & - & $\begin{array}{c}1 \\
(10 \%)\end{array}$ & $\begin{array}{c}3 \\
(30 \%)\end{array}$ & $\begin{array}{c}6 \\
(60 \%)\end{array}$ & 4.5 & High \\
\hline
\end{tabular}

Table 7. Mean Scores and Percentage of Affective Strategy

\begin{tabular}{|c|c|c|c|c|c|c|c|}
\hline Statement & 1 & 2 & 3 & 4 & 5 & Mean & Frequency Level \\
\hline $\begin{array}{l}\text { I encourage myself to speak English } \\
\text { even when I am afraid of making } \\
\text { mistakes. }\end{array}$ & - & $\begin{array}{c}1 \\
(10 \%)\end{array}$ & $\begin{array}{c}1 \\
(10 \%)\end{array}$ & $\begin{array}{c}2 \\
(20 \%)\end{array}$ & $\begin{array}{c}6 \\
(60 \%)\end{array}$ & 4.3 & High \\
\hline $\begin{array}{l}\text { I write down my feelings in a } \\
\text { language learning diary. }\end{array}$ & $\begin{array}{c}6 \\
(60 \%)\end{array}$ & $\begin{array}{c}1 \\
(10 \%)\end{array}$ & - & $\begin{array}{c}1 \\
(10 \%)\end{array}$ & $\begin{array}{c}2 \\
(20 \%)\end{array}$ & 2.2 & Low \\
\hline
\end{tabular}

\section{Metacognitive}

The mean scores pointed out that seven items are at high scale of frequency with mean scores ranging from 4.20 to 4.70 (Table 6). The items that exhibited the highest mean scores were "I try to find out how to be a better learner of English" and "I notice my English mistakes and use that information to help me do better." Interestingly, the students designed and strategize learning process by noticing their own weaknesses and paid attention when they listened to English-spoken conversations to help them become better at the language. The results suggested that students devel-oped awareness on how they learn best, they will rou-tine these strategies to efficiently obtain new informa-tion, and eventually became autonomous thinkers. Me-tacognitive strategy can positively impact students by helping them deepen their thinking pertaining to the content of the language. Additionally, the majority of the students agreed that they find ways to improve their English language. The respondents certainly re-gard English learning imperative as they pay more at-tention to self-study the language through starting con-versation in the target language and carry out extensive reading. The respondents seemed to delve deeper into the autonomous learning experience due to the academic expectation and a sense of competitiveness in obtaining high score for English. Besides, the students have to use English language to maintain their conversation with native speakers in the school. Thus, the use of metacognitive strategy seemed to further facilitate language learning in this study. Additionally, the students use English to converse in other subjects as well as English is the medium of instruction.
Affective

In regards to the affective strategies, the mean scores specified that two items are at high scale of frequency with mean scores ranging from 3.90 to 4.30 (Table 7). The item that displayed the highest mean score was "I encourage myself to speak English even when I am afraid of making a mistake", while the item that has the lowest mean score was "I write down my feelings in a language learning diary." Form Five language learner were required to use English as a mean to survive their major examination and conversing orally for the speaking assessment. Thus, the tendency of using more affective strategies can be seen as relatable to the form five learners as they need intrinsic and extrinsic motivations to enhance their language proficiency and compentency. Majority of the respondents reflected positively to the use of selfencouragement in speaking English even though they are concerned about making mistakes. According to Oxford and Nyikos (1989), the degree of expressed motivation was the single most powerful influence on the choice of language learning strategies. Besides, intrinsic and extrinsic motivation can also promote success in acquiring the target language (Khatib and Najafi, 2012). The findings in the present study supported the aforementioned statements and strengthened the fact that good language learners possessed an intrinsic motivation in learning a language. Adversely, most of the respondents were unwilling to converse about their feelings in regard to English language learning as they do not see the neccesity of it. The learners do not express their feelings through diary due to the fact that the use of diary is not as common as the use of social media among teenagers in this technological 
Table 8. Mean Scores and Percentage of Social Strategy

\begin{tabular}{lccccccc}
\hline \multicolumn{1}{c}{ Statement } & 1 & 2 & 3 & 4 & 5 & Mean & Frequency Level \\
\hline I ask questions in English. & - & - & - & 3 & 7 & 4.7 & High \\
& & & & $(30 \%)$ & $(70 \%)$ \\
\hline I practice English with other students. & - & - & $\begin{array}{c}1 \\
(10 \%)\end{array}$ & $\begin{array}{c}3 \\
(30 \%)\end{array}$ & $\begin{array}{c}6 \\
(60 \%)\end{array}$ & 4.5 & High \\
\hline
\end{tabular}

era. Moreover, the students might refuse to confide in someone else about their thoughts and feelings as they have a sense of uncertainties which might lead other unrelated matter such as low self-esteem.

\section{Social}

For social strategies, the mean scores directed that six items are at high scale of frequency with mean scores ranging from 4.00 to 4.70 for these strategies (Table 8). The item that presented the highest mean score was "I ask questions in English." Learning English in a supportive environment provides Form Five learners with many interactions opportunities to practice the language. Asking for clarification and repetitions as language learning strategies provided a meaningful learning experience and vast opportunities to the students. Based on the results, successful language learners sought opportunities to practice language and valued communication with other English speakers. The results also depicted that the high frequent use of the target language outside the classroom settings improve their communication skills. Additionally, the students frequently ask questions and interact with their peers or teachers using the target language. This particular result corresponds to the study conducted by Oxford (1990), in which she asserted that asking questions helps learners get closer to the particular meaning of words and aids their understanding in the target language. In view of that, Kamalizad and Samuel (2016), itemized that the conversation partner's response provides indirect feedback about the learner's production skills. It also encourages learners' conversation partners to provide sufficient input in the target language.

\section{DISCUSSION}

The results of the study discovered successful language learners were high users of language strategies. It supported the study conducted by Mohamed Amin Embi et al., (2001) in which he revealed successful language learners possessed a greater use of language learning strategies compared to poor language learners. Similarly, many previous studies explored the relationship between language learning strategies and learners' proficiency in which the findings portrayed that more proficient language learners employed a greater variety of language learning strategies. (Zakaria, Yunus, Nazri, \& Shah, 2016; Lee, 2010; O’Malley $\&$ Chamot, 1990). The total means of each category showed that metacognitive strategies $($ Mean $=4.466)$ are among the most frequently used strategies, followed respectively by social (Mean $=4.217$ ), cognitive $($ Mean $=4.036)$, compensation $($ Mean $=3.450)$, affective (Mean = 3.233) and memory strategies (Mean $=2.867$ ) found as the least used strategies among successful language learners. A close examination of the results of the study revealed that successful language learners at Tunku Putra School use metacognitive strategies for learning language skills more frequently. As can be seen from the result, the metacognitive strategies facilitate learning with the use of selfmonitoring and self-evaluation and allow learners to be more capable to regulate their own learning. Some examples of these strategies are using the target language with the native speakers and examining the mistakes which their teacher has marked in a written assignment and try to correct them. Additionally, this is in accordance with the study by Amin (2010) on successful language learner who often realize that it is best if the successful language learner initiate the conversation with either questions or comments. Hence, this will in turn motivate others in order to make language learning as easy as possible for the students, especially those with lower language ability.

The use of metacognitive strategies in this study show a high frequency and interestingly it also appeared to be the findings of various other studies. Such results can be obtained in studies done by Chen \& Xiao (2016) and Jalal and Karev (2011). Metacognitive strategies are mostly ideal for these successful students as the approach are students-centered and learners monitor and administer their own learning process. Zakaria, Yunus, Nazri, and Shah (2016) highlighted that in order to improve adolescent students' writing, learners should be exposed to strategies for planning, revising and editing their compositions as well as engaging them in activities which help them gather and organize ideas before writing the first draft. Not only 
that, the authors also emphasized that collaborative activities may improve the quality of writing as students work together to plan, draft, revise and edit their compositions. The present findings shows that both metacognitive and social strategies can be integrated during language learning especially during writing lesson. This is concurrent with the research done by Griffiths (2013) who further claims that successful language learners show capability in making decision and solve complex problem and are self-directed learners. This study is concurrent with the study conducted by Nazri, Yunus and Nazri (2016) who put forth that successful language learners possess the drive to work out matters with positivity, allocate sufficient time to settle various task, utilize an active mind, discover necessary information through different resources and understanding individual needs. All these are done without being told as successful language learners can make sense of their own learning.

Based on the result, it was found that successful language learners employed and favoured more indirect strategies (metacognitive, affective social) over direct strategies (memory, cognitive, and compensation). This can be inferred that successful language learners of this private school preffered to use strategies that utilize the learner's cognitive ability. Private school students are also not encouraged to memorize on grammatical terms as they are required to apply higher order thinking skills when answering their English papers. Since most of the students use the target language in constructing sentences in written form and mingle around with the learners of first language, the students do not rely on memory strategy as they pick up effectively when they apply metacognitive and social strategy. The aforementioned finding by Kamalizad and Samuel (2016), using metacognitive strategies is normally more applicable in an ESL setting where there are many people who speak the Lingua Franca (English). For instance, the students participation in the classroom and the community of friends offered the students opportunities to evaluate themselves and consciously reflect on their language production and language errors.

The findings also enlightened the fact that successful language learners reveal the interest to apply various strategies as a whole. In another words, a flexible learning approach can be found by successful language learners as the level of task and topics varies in the passage of time. What works for an individual may not necessarily be effective to other students. This result is supported by the study conducted by
Kitsantas et. al. (2016) which the researchers found out secondary school students normally apply a mixture of both cognitive and metacognitive strategies. Thus, the significant findings of this study serves as a good foundation in the field of language learning strategy context. Although the study revolves around secondary school students, it can be useful for different age groups across various curriculum. Additionally, the training of language learning strategy can be implemented to less proficient language learner in order for such learners to enjoy the opportunity to be at par with their counterparts. Exposing other language learners through proper training of language learning strategy help them to achieve better outcome in the target language.

\section{Implications}

This study has proven very successful in the identification of many students' beliefs about language skills in the ESL class. In sum, the notion that learning techniques or strategies might help language teaching areas is actually quite new, but it is clear that a successful language learner is doing something special or different in learning all language skills. What must be considered is that some students have an ear for language learning or that some students have an inherent ability for language learning, and when they combine this inherent ability with their effective learning strategies, they can provide themselves with an effective learning atmosphere. It is also important that teachers have a better understanding of their students' preference of strategy choices so that they may try to instruct them how to select a few strategies besides their own. Such awareness of teachers in respecting individual differences may lead them towards implementing a learnercentered class.Additionally, teachers should raise learners' awareness of the functions and usefulness of learning strategies so that they become more encouraged to select and use more appropriate strategies concerning all language skills. Thus, in order to lead learners to utilize those strategies, language teachers need to create a sufficiently input environment inside and outside the classroom. For example, they should involve their learners in a variety of communicative tasks. Thus, the role of a teacher should be modified as a facilitator, which motivates and encourages learners' active participation in the teaching and learning process.

The current research presents a wealth of information on the preference of successful language learn- 
ers on all language learning strategies use. However, it is no matter how carefully this research was conducted, the findings cannot be taken as conclusive. Thus, further research is needed in order to fully explore this area and the nature of the relationship between language skills, learning strategies and other variables such as achievement, motivation, anxiety of grammar learning, etc. According to Saad, Yunus, and Embi (2015), a good strategy can ease language learning. Thus, employing appropriate learning strategy in learning a language may expedite language attainment.

\section{CONCLUSION}

To conclude, the findings of this study provide a greater understanding of strategies use of successful language learners' participants' preferences of language skills learning strategies in particular. Generally speaking, the results of the study highlight that the strategies that are most used by the participants in this study were metacognitive and social strategies in regards to language learning. However, the least used strategy discovered was memory strategies. The results of this research show that the context of metacognitive and social strategies seems to play an important role in the learners' strategy use. Syllabus designers and material developers need to incorporate learning strategies, training into the curriculum that provide opportunities to learners to use such strategies. In terms of reading and writing skills use, students favored cognitive and metacognitive strategies at the highest level. Consequently, it seems that awareness of strategy use and mental processing traits might be the major factors for their strategy choices. The study also revealed that there was a positive outcome of the different language skills using all language learning strategies. In general, the learners, perhaps enrolled in an interactive way of learning process than the communicative one that give much attention to facilitate practical language learning for real life situation.

\section{REFERENCES}

Amin, M. Z. M., \& Embi, M. A. (2010). Strategies for Successful English Language Learning (SELL). Indonesia: Karisma Publications Sdn. Bhd.

Barrios, E. (2015). Spanish pre-service teachers of English: Perceived use of language learning strategies and its relationship with proficiency. Revista Española de Lingüística Aplicada, 28(1), 48-72.
Bin Samah, R., Puteh-Behak, F., Saad, N.S.M., Ali, S.M., Darmi, R., \& Harun, H. (2016). Effective Methods in Learning Arabic Language as a Foreign Language. Mediterranean Journal of Social Sciences, 7(3), 349.

Chamot, A.U., \& O'malley, J.M. (1987). The cognitive academic language learning approach: A bridge to the mainstream. TESOL quarterly, 21(2), 227-249.

Chan, H.W. (2016). Popular Culture, English Out-of-class Activities, and Learner Autonomy among Highly Proficient Secondary Students in Hong Kong. Universal Journal of Educational Research, 4(8), 19181923.

Cohen, A.D. (1996). Second language learning and use strategies: Clarifying the issues. Minnesota: Center for Advanced Research in Language Acquisition.

Cohen, A. (1998). Strategies in Learning and Using a Second Language. London and New York: Longman

Cohen, A. (2011). Strategies in Learning and Using a Second Language (2nd ed.). London: Longman

Cohen, A.D. (2014). Strategies in learning and using a second language. United Kingdom: Routledge.

Dörnyei, Z., \& Ryan, S. (2015). The psychology of the language learner revisited. United Kingdom: Routledge.

El-Omari, A.H. (2016). Factors Affecting Students'Achievement in English Language Learning. Journal of Educational and Social Research, 6(2), 9.

Embi, M.A. (1996). Language learning strategies employed by secondary school students learning English as a foreign language in Malaysia (Unpublished Doctoral Dissertation). School of Education, University of Leeds, Netherland.

Entwistle, N., \& Ramsden, P. (2015). Understanding Student Learning (Routledge Revivals). United Kingdom: Routledge.

Genc, G.; Aydin, S. (2011). Students' Motivation toward Computer-Based Language Learning. International Journal of Educational Reform, 20(2), 171-189

Goldenberg, C. (2013). Unlocking the Research on English Learners: What We Know-and Don't Yet Knowabout Effective Instruction. American Educator, 37(2), 4 .

Griffiths, C. (2008). Strategies and good language learners. In C. Griffiths (Ed.), Lessons from Good Language Learners (pp.83-98). Cambridge: Cambridge University Press

Griffiths, C. (2013). The Strategy Factor in Successful Language Learning. Bristol. United Kingdom: Multilingual Matters

Griffiths, C., \& Inceçay, G. (2016). New Directions in Language Learning Strategy Research: Engaging with 
the Complexity of Strategy Use. New Directions in Language Learning Psychology, 25-38. Springer International Publishing.

Hsiao, T.Y., \& Oxford, R.L. (2002). Comparing theories of language learning strategies: A confirmatory factor analysis. The modern language journal, 86(3), 368383.

Huang, I.C. (2015). Language learner strategies and English proficiency of college freshmen in Taiwan: Amixedmethods study. The Asia-Pacific Education Researcher, 24(4), 737-741.

Javid, C.Z., Al-thubaiti, T.S., \& Uthman, A. (2013). Effects of English language proficiency on the choice of language learning strategies by Saudi English-major undergraduates. English Language Teaching, 6(1), 35.

Kamalizad, J., \& Samuel, M. 2016. The Role of EFL/ESL Settings in Using Language Learning Strategies. The Asian EFL Journal Quarterly, 18(75).

Khamkhien, A. (2010). Factors affecting language learning strategy reported usage by Thai and Vietnamese EFL learners. Electronic Journal of foreign language teaching, 7(1), 66-85.

Khatib, M., \& Najafi, S. (2012). An investigation of motivational strategies used by L2 language teachers to promote English language learning: A case of Iranian high school students. Advances in English Linguistics, 1(4), 85-90.

Kitsantas, A., \& Cleary, T.J. (2016). The Development of Self-regulated Learning During Secondary School Years. Handbook of Motivation at School, 169.

Kobayashi, R. (2016). An Exploratory Study on Language Learning Strategies of Japanese ESS Students.

Lee, C.K. (2010). An overview of language learning strategies. Arecls, 7, 132-152.

Martínez, I.M.P. (1996). The Importance of Language of Language Learning Strategies in Foreign Language Teaching. Cuadernos de Filologia Inglesa, 5(1).

Md Yunus, M., Sulaiman, N.A., \& Embi, M.A. (2013). Malaysian gifted students' use of English language learning strategies. English Language Teaching, 6(4). http://dx.doi.org/10.5539/elt.v6n4p97

Embi, M. A. (2000). Language Learning Strategies: A Malaysian Context. Bangi: Penerbit UKM

Mohamad, A., Husain, F.M., \& Karia, N. (2014). A learning strategy profile of undergraduate university students in a public tertiary educational institution. International Journal of Arts and Commerce, 3(8), 172-184.

Naiman, N. (1975). The Good Second Language Learner. Tesl Talk, 6(1), 58-76.
Nazri, N.M., Yunus, M.M., \& Nazri, N.D.M. (2016). Through the Lens of Good Language Learners: What Are Their Strategies?. Advances in Language and Literary Studies, 7(1), 195-202.

O'malley, J.M., \& Chamot, A.U. (1990). Learning strategies in second language acquisition: Cambridge: Cambridge University Press.

Oxford, R., \& Nyikos, M. (1989). Variables affecting choice of language learning strategies by university students. The modern language journal, 73(3), 291300.

Oxford, R. (1990). Language learning strategies: What every teacher should know. New York: Newbury House.

Oxford, R.L. (1999). Relationships between second language learning strategies and language proficiency in the context if learner autonomy and self regulation. Revista Canaria de Estudios Ingleses, 38(1), 109126.

Oxford, R. (2011). Teaching and Researching Language Learning Strategies. Harlow: Pearson Longman.

Riding, R., \& Rayner, S. (2013). Cognitive styles and learning strategies: Understanding style differences in learning and behavior. United Kingdom: Routledge.

Rao, Z. (2016). Language learning strategies and English proficiency: interpretations from information-processing theory. The Language Learning Journal, 44(1), 90-106.

Razak, N.Z.A., Ismail, F., Aziz,A.A., \& Babikkoi, M.A. (2012). Assessing the use of English language learning strategies among secondary school students in Malaysia. Procedia-Social and Behavioral Sciences, 66, 240-246.

Rubin, J. (1994). A review of second language listening comprehension research. The Modern Language Journal, 78(2), 199-221.

Saad, N.S.B.M., Yunus, M.B.M., \& Embi, M.A.B. (2015). Exploring the Connection between Out-of-class Language Learning Strategies and In-class Activities. Journal of Applied Research in Education, 19, 36-49.

Seker, M. (2015). The use of self-regulation strategies by foreign language learners and its role in language achievement. Language Teaching Research, 20(5) https://doi.org/10.1177/1362168815578550.

Schmidt, R. (2012). Attention, awareness, and individual differences in language learning. Perspectives on individual characteristics and foreign language education, 6(27).

Shafie, S. (2013). Language Learning Strategies Used by Students Preparing for IELTS Examination. Journal 
of Interdisciplinary Research in Education (JIRE), $3(1), 71-80$.

Varasteh, H., Ghanizadeh, A., \& Akbari, O. (2016). The role of task value, effort-regulation, and ambiguity tolerance in predicting EFL learners' test anxiety, learning strategies, and language achievement. Psychological Studies, 1-11.

Wenden, A. (1987a). How to be a successful language learner: Insights and prescriptions from L2 learners. Learner strategies in language learning, 103-117.

Wenden, A. (1987b). Metacognition: An expanded view on the cognitive abilities of L2 learners. Language learning, 37(4), 573-597.
Yunus, M. M., Sulaiman, N. A., \& Embi, M.A. (2013). Malaysian gifted students' use of English language learning strategies. English Language Teaching, 6(4), 97.

Zakaria, S.M., Yunus, M.M., Nazri, N.M., \& Shah, P.M. (2016). Students' Experience of Using Storybird in Writing ESL Narrative Text. Creative Education, 7(15), 2107.

Zare, P. (2012). Language learning strategies among EFL/ ESL learners: a review of literature. International Journal of Humanities and Social Science, 2(5), 162-169. 